\title{
A Sartrean Approach to Ayé Șișe in Yorùbá Existentialism
}

\author{
Babalọla Joseph Balogun \\ Department of Philosophy \\ Obafemi Awolowo University, Nigeria \\ talk2joey@yahoo.com
}

\begin{abstract}
The place of the world in the life of individual human being cannot be underestimated. This fact has culminated in the high esteem in which the concept of the world is held in the existentialist thinking. Using the Sartrean existentialist methodological approach, the paper critically examines the notion of the world (ayé) in the existentialist thinking of the Yoruba people of Nigeria. The paper argues that although humans find themselves thrown into the world (ayé) amidst situations that are not of their own making, sometimes amidst untoward circumstances, the right mark of an authentic existence is siśse ayé which literally means "doing the world", rather than mere gbígbé ayé, that is, living in the world. The paper concludes that the hallmark of authentic existence is to be found in the act of "doing the world" rather than just living in it.
\end{abstract}

Key words: Ayé șísee, Jean-Paul Sartre, Existentialism, Authentic existence, Yorùbá ontology. 
"(Man) exists in the world, and his possibilities relate to his world, and more than that, to the particular situation in which he already finds himself in the world."

-John Macquarrie (1977, 62)

\section{Introduction}

The concept of "the world" plays a central role in existentialist thinking. This may not be unconnected to the fact that it serves as a necessary condition for the possibility of human existence and circumstances of that existence. Neither human beings - the core subject matter of existentialist philosophy nor any of their experiences, be it freedom, anguish, despair, anxiety, absurdity, facticity, choice and responsibility, even death, etc., all existential themes, is directly or indirectly meaningful outside the world. It is within the context of the world that the life of individual concrete human being makes sense or has meaning. An individual who never existed as a being-in-the-world, is no individual at all, or at best, not an individual to whom existential analysis of human condition is applicable. Also, it is in the world that human institutions, such as religions, marriage, politics, ideologies, education, cultures, parental guidance, among others things that inhibit individuals' exercise of their full freedom, are possible.

Among the Yorùbá, the world, which literally translates to aye, ${ }^{1}$ is a web of intricate whole, comprising both physical and non-physical forces, with neither exclusively meaningful without the other. This represents a significant difference from the classical existentialist conception of the world as fundamentally restricted to the concrete or the physical. The Yorùbá live essentially in a "theocentric world and as such, the world views, thoughts and ideas that define their attitudes and responses particularly to issues of human existence are saturated by transcendental metaphysical considerations" (Olajide 2011, 7). Of course, this position, which has been especially popular among earlier African scholars such as Bolaji Idowu (1962), J. S. Mbiti (1969), and M. A. Makinde (1988) has been heavily disputed by other scholars among which are Kwasi Wiredu (1980) and Tunde Bewaji (2006). However, it is instructive to point out that scholars in the latter group do not deny that Africans are religious; what they deny is the claim that African moral system is inextricable from African religion.

This paper enquires into the Yorùbá understanding and use of the concept of ayé in their existentialist thought-system. The paper starts with a linguistic-phenomenological account of the concept of ayé, with a bid to revealing

1 This can also be translated as ilé-ayé. However, I shall stick to ayé in this essay for a reason that will become obvious in the course of the essay. 
two contextual significations within the linguistic culture/philosophy of the Yorùbá people in light of which their existential thought about the concept can be understood. A well-informed analysis of ayé, such as it is intended here, has the merit of demonstrating the place of humans in it, coupled with its role in their understanding of their human conditions and coping strategies. Subsequently, the paper argues that although humans find themselves thrown into the world (ayé) amidst situations that are not of their own making, sometimes amidst untoward circumstances, the right mark of an authentic existence is șișe ayé which literally means "doing the world", rather than mere gbígbé ayé, that is, living in the world.

\section{Ayé in Yorùbá Linguistic Convention}

The concept of ayé could be approached from diverse theoretical standpoints, depending on the diverse ways in which it is used within the Yorùbá linguistic convention. Some of such theoretical standpoints can be identified, namely, cosmological, existentialist, metaphysical, and moral, among others. In this paper, ayé shall be used in both its cosmological and existential contexts. The reason for this is fairly clear. As the subsequent part of the section intends to show, the existence of the cosmological context of ayé is sufficient for the existential context of ayé to take place. In other world, without the former, the latter is not only impossible but also unthinkable. For analytic convenience as well as to avoid confusion as the paper proceeds, I shall prioritise, both chronologically and logically, the two contexts of ayé by referring to the cosmological context as ayé $e_{1}$ and existentialist context as ayé $e_{2}$.

$A y e_{1}$ is an ecological confinement in which individuals are expected to fulfil their destinies. B. M. Ibitokun refers to this world (ayé $e_{1}$ ) as "the earth which is the measure of the present, and the locus of mortals and where you and I, in the form of existence, dramatise our distinctive destinies" (2014, 21-22). Here, ayé ${ }_{1}$ is conceived in terms of a stage, where individuals come to play their roles, and then revert into the dark back-stage. Balogun and Oladipupo have noted that primarily, ayé ${ }_{1}$ is used to mean the world in which existence takes place; that is, the objective or material world (Balogun and Oladipupo 2013). Existence here is to be understood in its most generic, non-technical, sense to incorporate both animate and inanimate objects as well as human and non-human beings. To this end, ayé ${ }_{1}$ can be likened to a vessel that wraps up all kinds of beings, human and/or otherwise. This vessel provides a large interactive meeting point for all things that physically are. In a specific relation to human beings, ayé, also called ilé ayé, is contrasted with ọrun or àjùlé ọrun (heaven), from where humans are not only alleged to have come but to 
where they are believed to return after death. Hence, the Yoruba would say: ayé l'ọjà ơrun n'ilé (the world is a marketplace; heaven is home).

Ayé is broadly divisible into terrestrial habitat (orí ilẹ) and aquatic habitat (inú omi). Terrestrial environment consists of all life forms in and upon the surface of the earth, including in the houses, in the bushes, forests, deserts, swamps, etc. Aquatic environment, on the other hand, shelters all forms of existence naturally found in the waters, i.e., in oceans (òkun), seas (ọsà), rivers (odò tó ń șàn), pools (adágún odò), and other smaller bodies of water. These two components of the world are important to man's survival not only in the sense in which they help to keep his biospheric environment balance and biologically conducive for living, but also in the sense in which they equip him with the necessary apparatus required for fulfilled existence.

It is important to note that out of all the constituents/occupants of ayé, only èniyàn (human beings) are aware of their existence. Perhaps this supports the etymological derivation of èniyàn as ẹni-tí-a-yàn (i.e. "the chosen one") (See Karenga 1999, 2009). Man's element of "chosenness" makes him the favourite, the earthly king over other forms of creation, whereby he assumes the role of a "co-ordinator" of the world (ayé ${ }_{1}$ ). To describe man as "chosen", according to Karenga, "carries with it a uniqueness, in that it presents the highest level of humanism in its inclusion of all humans as chosen,... as is the case for virtually all other traditions who self-define as chosen, elect, or recipients of endowed status" (Karenga 2009, 239). Such chosen status commits man to determining to what extent other things in the world are useful or not. This is what the existentialist means by saying that man is a value-giver. To man, other things in ayé are mere instruments, so that the relation between man and others is that of master and slave. It is in these others that human's requirements for food, shelter, clothing, medicine and other general upkeeps are adequately met. When his appetite transcends the bound of what nature has readily available for him in stock, he devises a means of creating it out of the existing components of the universe, using the power of his nature-endowed intellect.

On the other hand is the ayé $e_{2}$. This is the world as represented in individual's existence. $A y e_{2}$ is the lived, concrete life of an individual. It is the totality of individual's engagement with the physical world (ayé $e_{1}$, the sum total of the nothingness filled, between birth and death. Unlike ayé, shared by all earthly occupants (as it were), ayé $e_{2}$ is in the realm of loneliness, a world cohabited by none, except the owner thereof, a road travelled all alone. It is the territory of subjectivity and crude individuality. It is also a realm of freedom, for as noted by Olajide, "subjectivity is undoubtedly rootless unless it is buried in human or individual freedom" $(2011,2)$. This human freedom makes the individual the best expert in his or her own affairs. This point is consistent 
with the Yorùbá belief that each individual is a unique being in the world, and that, having been sent to the world (ayé $)$ to fulfil a particular destiny, he or she alone has the mandate to deliver the message wrapped up in his/ her destiny. The entry into this realm is revealed through a self-awareness brought about by what Ogungbemi refers to as self-consciousness. Self-consciousness is an attribute possessed only by human beings, culminating in the existentialist demarcation of the "being" of humans from those of brutes. Ogungbemi writes:

To the Yoruba, to be self-conscious is to be self-aware of oneself and to be self-aware of oneself is to have cognition and recognise who you are and what you are as an individual... Also being a self-conscious individual, man is able to raise the question of how he can find meaning and purpose in life. It is when an individual becomes aware of himself that he can actually know that self-awareness individuates, since individuation is a means to self-actualisation or self-authentication, it differentiates the quality of individuals. Even though individuals are self-conscious of their "beings", they do not necessarily actualise their "beings" on the same level (2007, $119)$.

The description of the individual's life as a realm of loneliness appears curious and inconsistent with the prevalent idea of the human person among some African scholars. According to this trend, an individual, within the African context, is only definable in relation to others, human and non-human alike. For Mbiti, "the individual does not and cannot exist alone except corporately." Being a part of the whole, "he owes his existence to other people, including those of the past generations and his contemporaries" $(1969,106)$. This suggests no possibility of "my life" or "your life" (i.e. lonely life) within African ontological psychology of the individual person. Such may not be totally correct from a typical Yorùbá perspective, however. From the Yorùbá conceptual perspective, a person does not lose his or her individuality because of his or her membership in a group/society (Famakinwa 2010; Ogungbemi 2007). Certain aspects of life are rather understood individually (Balogun and Oladipupo 2013). For instance, a simple refusal to a sincere piece of advice, especially from an older member of the family, may incite a response such as: èmi ni mọ l'áyé ara mi, "it's my life." This suggests the possibility of each individual living in his own world.

Ayé ${ }_{2}$ is a temporal phenomenon. This element of temporality, betraying a mark of man's finitude, is better understood in terms of period or phase. An expression of this temporality can be found in the Yorùbá saying, İgbà l'ayé ("the world is in phases/periods"). Time, phase, or period is of essence to ayé ${ }_{2}$ 
perhaps because of the finitude of existence. The reality of death makes the individual's existence a matter of time. To emphasize the individuality factor attached to $a y e_{2}$, the Yorùbá divide individual human life into three periods/ phases, corresponding to the linear division of the day into morning (igbà àárọ), afternoon (igbà ọsán), and night (igbà alẹ). Each individual person has his or her own separate periods, which are a metaphor indicating his or her progression towards an essence he has conceived for himself, and ultimately, towards death. According to Sartre,

...man is, before all else, something which propels itself towards a future and is aware that it is doing so. Man is, indeed, a project which possesses a subjective life, instead of being a kind of moss, or a fungus or a cauliflower. Before that projection of the self, nothing exists; not even in the heaven of intelligence: man will only attain existence when he is what he purposes to be $(1956,291)$.

İgbà àárọ (morning period/phase) represents roughly the period of the individual's birth up to age thirty. ${ }^{2}$ This period offers the individual the opportunity to determine what shape his/her later phases would take. One's parents, who are culturally expected to supervise the foundation for whatever one would later become in life, influence an important part of igbà àárọ. However, though parents have a role to play in the shaping of the individual's budding life, the Yorùbá believe that the onus of becoming successful or otherwise later in life rests significantly with individual himself/herself; it is a choice that each individual will have to make early in life.

İgbà ơsán (afternoon period/phase) and igbà alẹ (night period/phase) are like superstructures built upon the foundation laid during ìgbà àárọ. İgbà ọsán covers roughly the period between age brackets of thirty to sixty-five years. This period marks the productive age, and in most cases, the post-school/ apprenticeship period. It is the time for establishing families (this does not mean that some, especially women, do not establish families earlier than this),

2 It should be stated here that in so dividing man's life, the Yorùbá provide no strict principle that can help to demarcate one phase from another. Perhaps the metaphoric division of existence into three linear points of àárọ, ọsán, and alé, is found suitable because it helps to explain the progression of individual life: the beginning (or early time), middle, and the end. However, this conception may raise the question whether an average person completes this process or not. If everyone does, it will follow that a person that dies at the age of twenty dies at night, so does an infant, which will be absurd. So it could be claimed that based on the teaching of experience, people can die both in the morning, afternoon or night phase of their life. Our grouping of each phase as: one to thirty, thirty to sixty-five, and sixty-five to death is therefore arbitrary in the sense that it is not one that may be generally agreed to, but it still serves our purpose in this paper. 
bearing and rearing children, and achieving intended goals for individual life. In general, a time for realizing one's dream, igbà òsán is characterized by attempts at realizing life's numerous projects. İgbà alé is a time for reflection over life during igbà àárọ and igbà ọsá. It is the period when people atone for their errors or shortcomings, when experience dictates life and when the individual becomes a repository of traditional knowledge and wisdom. It is also the period when the individual prepares for death with all its associated beliefs. Although it comes at the end of the individual's life, the Yorùbá believe that igbà ale is the most important phase of human life, hence they pray K'álé san wá ju àárọ lọ, "may our nighttime be more prosperous than our morning time." Perhaps, this may not be unconnected to the belief that it is this period that one reaps the fruit of decisions taken and choices made in the earlier periods of life. This suffices to mean that the quality of one's igbà alé depends on the quality of the use to which one has put one's freedom during igbà àárọ and igbà ơsán. The Yoruba will say, àgbà tí ò f'àárọ sișé yóò f'alẹ síṣẹe - an elder who did not spend his early life working, will spend his old age in poverty.

One fundamental difference between the two contexts of ayé described above, relevant for our purpose in this paper, is that while ayé is passive and inert, ayé $e_{2}$ is active. Another way of putting this difference is to say that whereas the former is in the realm of facticity, the latter is in the realm of possibility. In existentialism, facticity is the condition to which an individual is born, which can neither be denied nor altered. It is the existential given over which man has no control. The world (ayé $)$ is, all the way, the same: a place where certain species of creation find themselves in. It is the world of which Sartre speaks that man finds himself thrown in without direction. The world (ayé $e_{1}$ is, forever, what it is. However, ayé ${ }_{2}$, conceived as possibilities brought about by conscious choices of the concrete individual that exists in the world (ayé ${ }_{1}$ ) are not as passive. To repeat John Macquarrie, "(Man) exists in the world [ayé ${ }_{1}$, and his possibilities relate to his world [ayé 2 ], and more than that, to the particular situation in which he already finds himself in the world [ayé ${ }_{1}$ ]" (Macquarrie 1966, 62). Although man has no control over the situations in which he finds himself in the world (ayé $)_{1}$, he is completely responsible for what he makes out of the situations in which he already finds himself. Perhaps this is why Sartre reasons that human beings are beings in whom "existence precedes essence." This means that "man first of all exists, encounters himself, surges up in the world - and defines himself afterwards" (Sartre 1956, 290). For Oke,

What man is, is for each person what he or she makes of his or her life. This is what they mean by saying that existence is prior to essence, and 
existentially interpreted ... this is why the Gods or any external forces are not to blame for the weal or woe of the world $(2001,128)$.

In spite of the foregoing difference between ayé $e_{1}$ and $a y e_{2}$, it is instructive to note that the two worlds are not conceptually separable from one another. The subjective world is a subset in the objective world, and hence inexpungible from it for as long as the former lasts. This is because, as noted earlier, ayé predates each individual ayé $e_{2}$, and outlasts it. An individual is born into the world (ayé $e_{1}$ ), lives within it, and will die within it (Olajide 2011). It is in the world (ayé $\dot{1}_{1}$ that each individual makes choices that determines the shape of his/her world (ayé ${ }_{2}$ ). The implication of this is that, though they are separate worlds, the activities in ayé $e_{2}$ impact on, to a large extent, ayé ; and this may be positively or negatively. In Sartre's existentialism, the choices that an individual makes go far beyond his/her subjectivity (1956, 290-291). When we choose one course of action rather than another, we choose not only for ourselves, but for all humans, since our choice of the action implies that we would have willed that all humans choose the same course of action in a similar circumstance. Now, if the world (ayé $)$ is conceived as the Other, including other human beings, it means choosing for oneself is choosing for the world. The ultimate conclusion here is that, although ayé ${ }_{2}$ is existentially different from $a y e_{1}$, the quality of the former rubs off the latter.

In what follows, I shall attempt a strictly existentialist reading into the concept of ayé within Yorùbá existential thought. I shall argue that the Sartrean concept of authentic existence is realised within the Yorùbá existentialist concept of ayé șíse.

\section{Ayé Șișe as the Signpost of an Authentic Existence}

The best way to start this section, it appears, is to clarify the existentialist concept of authentic existence, and then make a case for how it is realized in Yoruba existentialism through the concept of ayé șisse. Authentic existence is one based on the complete autonomy of the individual person as a choice-making animal. In Reisinger and Steiner's opinion, to be "authentic is to be in touch with one's inner self, knowing one's self, having a sense of one's own identity and then living in accord with one's sense of one's self" (Reisinger and Steiner 2006, 65). That is, an authentic life is lived in consonance with the dictate of the self, rather than imposed on the self from the outside. For Sartre, authenticity requires taking full responsibility for one's life, choices and actions. This way, the concept of authenticity helps to sharpen 
the dichotomy between the self and others, that is, between the two worlds; and the ideal relationship that should hold between them.

To be authentic therefore must include an attitude of conscious rebellion or revolt to the influx of all external forces under whose weight an individual becomes lost in the crowd. Rebellion here is a positive, and, in fact, a desirable or necessary attribute of human existence because, besides its origin from the exercise of absolute freedom, it confirms the authenticity of the rebellious. Thus, to exist authentically is to lead a life devoid of impurities originating from such facticity as parents, culture, religion, morality, fashion, peer influence, education, politics, etc. By an act of constant bombardment, these forces invade our beings, leaving us existentially disoriented and alienated. Human beings can only be said to have authentically existed after they have subdued the force of these agents. Sartre writes:

... we remind man that there is no legislator but himself; that he himself, thus abandoned, must decide for himself; also because we show that it is not by turning back upon himself, but always by seeking, beyond himself, an aim which is one of liberation or of some particular realization, that man can realize himself as truly human $(1956,310)$.

This point projects Sartre's understanding of the subjectivity of each concrete individual, based on the alleged non-availability of objective values from which human can choose to guide the course of his/her existence. Lack of objective values demands that humans look nowhere for a direction on how to live. The best place to look, therefore, remains within himself. Olajide also argues, in consonance with Sartre, that man "must by an act of deliberate conscious choice reject the luxury and comfort of subsuming himself within the dictates of the faceless crowd or the herd, a preference which Jean Paul Sartre would later call bad faith typifying the inauthentic escapist existence of Kierkegaard" (2011, 3).

The question of how an authentic existence is realised within the Yorùbá concept of ayé sís can be addressed at this point. The phrase, śayé ally, "to do the world", is a rather complex expression in the Yorùbá language.

3 The phrase s'ayé is the verbal form of the noun, ayé șíse. Here it could be asked that when one uses the phrase, s'ayé - does the world - which of the two contexts of ayé is one referring to? Well, a response to this question has been anticipated above where I tried to show the relationship between ayé ${ }_{1}$ and $a y e_{2}$. To repeat here, an individual who exists authentically by consciously choosing his/her action and hence being responsible for his life, is equally choosing and hence responsible for the whole of humanity. In other words, since his/her life is a subset of the world, then s/he is at the same time does both worlds. This point will be made clearer in the course of this section. 
In its most basic usage, it means a tendency for personal survival in a world (ayé $e_{1}$ believed to be characterized by fierce competitions and a high possibility of misfortune. To this end, to do the world, is to, among other things, remain resilient in the face of the unhealthy possibilities that the world (ayé $e_{1}$ readily offers. An individual who does not șayé does not have the requisite stamina to survive in the world (ayé $)_{1}$. Of such a person, the Yorùbá will say, $a y e_{1}$ ń șe é - he's being done by the world (he's under the influence of the world). Although it is often given a metaphysical interpretation to mean that such individual is under some spiritual spell, the statement can be existentially interpreted to portray an individual who has no charge over his or her life.

Two things are discernible from the foregoing, therefore: it is either one does the world or one is being done by the world. On the one hand, it is deducible that the Yorùbá see the act of doing the world in a positive light. Thus, when one is said to s'ayé, one is seen as possessing the requisite ingredients for a fulfilled or authentic existence, implying that one is fit for the business of quality existence. In contrast, to be done by ayé is to be in negative circumstances. The Yorùbá consider it a curse for one to be described as being done by ayé, for it not only portrays the individual so described as having lost touch with his/her original self, but it also shows him/her as a misfit of a sort.

Another way of looking at the phrase, s'ayé-to do the world-is by understanding it to be a shortened form of a longer phrase. The phrase may be completed as șayé ire - to do the world good. As noted by Karenga, "at the heart of Ifá moral anthropology is the ethical teaching that humans are chosen by the Creator to bring good into the world and that this special status and task are the fundamental mission and meaning of human life" (2009, 239-240). The call to the world good is a clarion call for an individual to live a morally worthy life, as it is through this that an ideal earthly condition is achievable for all. A popular Yorùbá folk song says: E ș’ayé e re kó dára; ẹni ayé kàn e șée re ("do the world good for it to be good; he whose turn it is to be in the world, do it good"). The rationale behind this call can be seen from its functional perspective: doing the world good establishes a sufficient ground for any concrete individual to be what or who he or she chooses to be without being constrained in the use of his or her freedom.

Some phenomenological clarification is required here. At a personal level, there are two kinds of ayé 2 : mine and others'. The former is ayé mi (my world/ my being/my life) and the latter, ayé aláyé (subjective others). (Notice that ayé aláyé is part of the world (ayé $e_{1}$ because it falls outside my subjectivity.) In contrast to ayé mi, ayé aláyé refers to self-consciousnesses other than mine, the presence of which makes me believe that other subjects exist beside me. Ayé aláyé comes in different guises. One of these can be found in the concept 
of idílé, the Yoruba word for family. İdílé consists mainly of bàbá (father), ìá (mother), and alájọbí (siblings), which may include ẹgbọ́n (older siblings) and àbúrò (younger siblings). Consisting mainly of people with whom one is acquainted early in life, these people are the closest to an individual in the social web/relation. The extended family structure prevalent among traditional Yorùbá complicates the web of influence, raising it beyond the immediate members of one's nuclear family to others such as uncles, aunts, cousins, nephews, nieces and, if they are still alive, grandparents and even great-grand parents. All these members are my e bi-members of my family. Beside members of family, an individual also shares his/her social destiny together with others, including, ọkolaya (spouse), ọmọ (children), ọrẹ (friends), ojúgbà (agegroup), ará àdúgbò (neighbours), àgbà (elders), and other social relational possibilities, which climax at ọmo aráyé lápapọ-humanity generally.

Now, the wills of these beings of other have a way of invading my being if my being lets them. The Yorùbá saying, ogun l'ayélijà l'ayé ("life is war/strife"), helps to explain the nature of this individual-others invasion. One may ask, if life is war/strife, against whom is the war/strife fought? An answer to this question may come in form of the non-physical forces that human beings have to contend with on their way to self-actualization. The Yorùbá ontology of the universe allows for the existence of non-physical or, if you like, spiritual, forces who are legitimate co-occupants of the world (ayé) with human and other physical beings in the universe. These forces range from personal malevolent spirits such as witches (àjẹ́), and wizards (oṣó), etc. to potent non-personal forces, the so-called ajogun, such as death (ikú), diseases (àrừn), loss (ófỏ), paralysis (ègbà), big trouble (ọràn) curses (èpè/ègún), imprisonment (èwọn) and affliction (èșe) (Dasaolu and Oyelakin 2015, 25). Ogungbemi, for instance, may not agree that these forces constitute threats to the life of an individual. He refers to the belief in witchcraft as "the practice of fault-finding among relatives and neighbours"; and "the end result sometimes, if not always, is anxiety, fear, suspicion, hatred and bitterness" (2007, 105). This submission is debatable. If put within the existentialist context, however, the question can be answered in respect to human forces. These are not the physical persons who surround him/her in the world, but with the non-physical components of their beings which may include their ideas, moral systems, cultures, political inclinations, to mention but a few of them. It is perhaps of these forces that Olajide writes when he submits, rather plaintively, that "the prospect of an authentic self-discovery and self-actualisation by the individual particularly within the African socio-cultural context is rather dim and slim, and where it seemingly exists at all, it is severely threatened" (2008, 113). According to Karin Barber, "Yoruba cosmology presents a picture of a man, a solitary individual, picking his way (aided by his orí, destiny chosen 
by himself before coming to earth) between a variety of forces, some benign, some hostile, many ambivalent, seeking to placate them and only himself with them in an attempt to thwart his rivals and enemies in human society" (1981, 729). Ibitokun also has the same opinion about human struggle:

We ought to know that our nature remains the battlefield where factional, warring modules of id, culture, religion, economics, philosophy, governance, productions and distributions, etc., atavistically fight it out against one another (Ibitokun 2014, 24).

What Ibitokun refers to above as "warring modules", Ogungbemi calls the "polarities of existence." It may be tempting then to conclude, as Ogungbemi does, that "there is always, therefore, an observable tension in polarity between the individual and society" $(2007,146)$. Like the Hobbesian state of nature, existence is a war of one against all. Authentic existence demands that an individual be the chief dictator of his or her life. As declared by Oke, "man's salvation lies in his own hands, in his personal action, and not in the action or inaction, decree or plea of an agency or force external to him, be such agency or force divine, oracular or secular" $(2001,132)$.

The foregoing may be approached from another perspective. Consider the Yorùbá saying, ojà l'ayé (the world is a marketplace). This saying presupposes that other persons beside the individual are mere co-marketers with some that are close, and yet some others who are far. As a co-marketer, each individual comes to the market for different reasons. Some go to the market and get distracted by the noise of the marketplace (ariwo ojà). These are people who allow other people's opinion to rule their lives. Such people may be described as suffering from bad faith, to use Sartre's concept for those who live in-authentically. The Yorùbá would say, ohun tí a bá wá sộjà ló yẹ kí a gbá'jú mọ́; ki i șe ariwo ojà ("it is what we go to market for that should be our primary focus; not the noise of the marketplace").

Some may dismiss the foregoing as representing Western individualism, and hence, not representative of the African, especially Yorùbá, conception of the human personality. The objection to the above characterization of the individual may be rejected by some scholars of the African culture. This is because, for them, the individual is taken to be a culture-bound person who lacks his own conception of the good life, personal will, and who does not exist except in relation with others in his community. L. O. Bamikole, for instance, claims that man in the African context is a product of culture, and by this, he means that "man is a social being whose existence depends on others in the society. This is the origin of the assertion, 'I am because we are', which 
is the direct opposite of Descartes' 'I think therefore I am'” $(2004,102)$. Bamikole also argues, from a different perspective, that:

... an individual is an integral part of his culture. But what is culture is a product of individual brains, and it can be said then that an individual is also part of the determining factors of his actions. It is in this way that the individual agent is reconciled with culture. Thus, when an individual is conforming to the customs and norms of his culture, he is in essence obeying the laws he has legislated for himself (ibid, 104).

Being man-made, some elements of culture cannot be immune to human error. Moreover, certain aspects of culture have the possibility of being outdated. A particular element of a culture may lose its relevance due to modernity, civilization, or a mere change in vogue or taste. Beside these flaws, cultures are templates which only apply to the general aspects of people's lives, but which do not give direction on how an actual human person should live his or her life in an authentic way. For instance, culture may prescribe marriage for adults, give direction on the marital responsibilities shared by spouses, etc. But it clearly leaves the individuals with the choice of whom to marry, or whether to marry at all. This is a personal decision that an individual will have to make. Culture therefore becomes utterly irrelevant in critical aspects of the individual's life.

What is said about culture above is equally applicable to some other features of our world (ayé ) $_{1}$. Consider technology, for instance. Technology, to be sure, is an inextricable part of contemporary life. It provides platforms for easy achievement of human projects which, without it, might either be impossible or quite laborious and expensive to achieve. This has made technology eat deep into contemporary consciousness that so many lives are blindly lost in it. However, technology, like culture, provides no standard for living through which historical human person could achieve authenticity. It should be noted that every technology is a way of life conceived by a particular inventor and imposed on other through its distribution and use. An inventor of a piece of technology has a dream. The users of such piece of technology help realize the dream.

It might help that we put the verb șe in a proper, existentialist perspective in our analysis of the concept of ayé șișe. As a Yorùbá verb, șe literally means "to do". Among other significations, "to do" may mean "to act", "to cause something (to happen)", or "to perform something", "to build" etc. It could be observed that these alternative meanings of the verb șe have a unifying commonality, namely, they all imply bringing about something which, hitherto, was not. For Sartre, the phrase, "to act," for instance, is: "to modify the shape 
of the world; it is to arrange a means in view of an end; it is to produce an organised instrumental complex such that by a series of concatenations and connections the modification effected on one of the links, causes modifications throughout the whole series and finally produces an anticipated result" (1981, 268). Hence, "to do" is to aim primarily at what is not, as against what is. This implies making or causing a change in the way the world (ayé $)$ is. Notice that this change may come as either an addition to the world or subtraction from it. Either way, acting leaves the world either better or worse than it was prior to its occurrence, although it does not change the world from what it is.

Although an action is always followed by a modification (i.e., the coming into being of what was not) of the state of affairs in the world (ayé $e_{1}$, it is not the case that any time there is a modification in the state of affairs, an action has taken place. For sometimes, it is possible for a modification of the state of affairs not intended by the subject to occur. That is why, for Sartre, "the careless smoker who has through negligence caused the explosion of a powder magazine has not acted." But on the contrary, "the worker who is charged with dynamiting a quarry and who obeys the given orders has acted when he has produced the expected explosion; he knew what he was doing, or if you prefer, he intentionally realised a conscious project" (ibid.). The key to the difference between these two occurrences is intention: whereas the former does not arise deliberately from the subject's intention, the latter is a consciously intended project, whose consequence is foreseen before the action actually took place. This, however, should not be taken to mean that one must foresee all consequences of one's action from the onset. For example,

The Emperor Constantine when he established himself at Benzatium, did not foresee that he would create at the centre of Greek culture and language, the appearance of which would ultimately provoke a schism in the Christian Church and which would contribute to weakening Roman Empire. Yet, he performed an act just in so far as he realised his project of creating new residence for emperors in the Orient. Equating the result with the intention is here sufficient for us to be able to speak of action (ibid, 269).

The point to note from the foregoing quote is that, "doing the world" involves taking a conscious action towards the realization of a no-thing; that is, causing to be that which was not. This is, according to Sartre, the essence of the being of man. Thus, "all intentional action must by definition be an attempt to change the world in some way, to bring about what the agent believes to be desirable, but not already the case" (ibid, 267). The desirable state of affairs comes to being through the existential creation of the subject, through conscious action. 
A clearer perspective to the foregoing may be provided by considering the passive counterpart of ayé sisise, namely, ayé gbígbé ("living in the world [ayé ${ }_{1}$ "). The latter invokes the ideas of space and quantity. To live in the world is to occupy a specific region of the world at a time. This amounts to the number of spaces occupied in the world at a particular period defined by individual's life from birth to death. Living in the world thus invokes the idea of passivity because it is the given: one just happens to find oneself thrown into the world, without having requested it. As Olajide puts it, man "suddenly just found himself in the world alone without his consent and he must confront his aloneness by naming his values" $(2006,241)$. Existentialists of Sartrean orientation refer to this as the contingency of human existence. According to Priest,

Existence is contingent. There might as easily have been nothing as something and, in particular, one's own existence is inherently meaningless and contingent. Only particulars exist and things being what they are depends on the fragile contingencies of human language and faces the unsolved problem of induction. The effect of this Existentialist vision on those who experience it is a most profound sickness and anxiety $(2001,24)$.

A corollary of ayé gbigbé is iwà l'áyé-being in the world, or being alive. Being alive is a necessary and sufficient condition for authentic existence, although it is possible to be in the world without doing the world. In other world, authentic existence is only possible within the context of aliveness. Although being alive makes authentic existence possible, it does not follow that all people in existence live authentically. This means that authentic existence is an addition to being alive. Hence, to live authentically, one has to live above the passivity of being alive. One has to add commitment to living to produce human essence. This means that being in the world does not guarantee one's essence; what guarantee human essence is the totality of choices made in a life time.

To wrap up this argument, it is apt to point out, in a brief addendum, the role of responsibility in ayé-síșe. It has been argued, via Sartre's ontology, that the being of humans is essentially free. As Sartre argues, being human is synonymous with being free. In other words, for him, "The only sense in which we are not free, it seems, is that we are not free not to be free" (ibid, 140). This freedom is the freedom to choose; and with it comes responsibility. To be responsible for what individuals do in Sartre's sense "is to say that they do it, they could have refrained from doing it, and they are answerable to others for doing it" (ibid, 192). One may then see that responsibility is inextricably tied to the consequence of the choice made: without freedom to choose, there 
would be no responsibility. Sartre's insistence that there is no situation in which man has no choice therefore implies that people are always responsible for their actions and inaction, and ultimately, for what they are. In recognition of this burden of responsibility, the Yorùbá would thoughtfully warn: $a k i$ í ní kí ọmọdé má d'ẹtẹe, tí ó bá lè dá inú igbó gbé ("no one forbids a child from becoming leprous, as long as he has he will to live a solitary life in the bush").

\section{Conclusion}

In a convocation address at Stanford University in 2005, Steve Job charged the graduating class with the following:

Your time is limited, so don't waste it living someone else's life. Don't be trapped by the dogma which is living with the results of other people's thinking. Don't let the noise of other people's opinion drown out your own inner voice. And most important, have the courage to follow your heart and intuition. They somehow already know what you truly want to become. Everything else is secondary.

Job's admonition above appears persuasive, but it is the actual nature of human beings. Existence is all about making choices, but choices are not manufactured from ready-made products, the so-called "objective principles" that may aide the choosing individual to make the right choice. Such products are not readily available: the available ones, for examples, culture, religion, education - western or otherwise - family, parental upbringing, peer pressure, and the rest, what Ibitokun earlier refers to as "warring modules", have all been shown to be unhelpful in any significant, self-fulfilling way.

What does an individual do, given the absence of objective standard or principle, to authentically exist? As I have argued above, the individual has no choice than to keep doing (or acting), which is a conscious act of choosing in a way that keeps the world (ayé $e_{2}$ ) creatively evolving from what it is to what it is not. There is no escaping from this; hence, each person is what s/ he makes out of his/herself. To refuse to act is itself an act. If all instances of acting attract responsibility, then a refusal to act is not an exception. The realisation of this by the individual confers a certain feeling of forlornness on him/her, a feeling that confirms the true nature of the business of existence as irredeemably personal. This is the personal world (ayé $e_{2}$ ) of the individuals with which s/he shares with none else. Whatever each individual does with this world is entirely left to him or her. However, it ultimately determines the 
quality of each person's life - that is, whether such life be described as authentic or otherwise. ${ }^{4}$

\section{Works Cited}

Barber, Karin. "How Man Makes God in West Africa: Yoruba Attitude Towards the Orisa." Africa, 51(1981).

Balogun, Babalola J. and Oladipupo, S. L. "Ole Jija: Rethinking theft in the Yoruba ethical system." Inkanyiso: Journal of Humanities and Social Sciences, 5, 1 (2013), 31-40.

Balogun, Babalola J. "Ibi: An Examination of the Yoruba Traditional-Existentialist Conception of Evil." Thought and Practice: A Journal of the Philosophical Association of Kenya (PAK), 6, 2 (2014), 55-73.

Bamikole, L. O. "Culture and Agency in Yoruba (African) Metaphysics: Implication for Cultural Retention and Transmission in Africa and in Diaspora." Journal of Philosophy and Related Disciplines, 2, 2 (2004), 97-115.

Bewaji, J. A. I. "Ethics and Morality in Yoruba Culture”. In Kwasi Wiredu (ed.) A Companion to Philosophy. Malden: Blackwell Publishing Ltd., 2006.

Famakinwa, J.O. "How Moderate is Gyekye's Moderate Communitarianism?" Thought and Practice: A Journal of the Philosophical Society of Kenya (PAK). 2 (2), 2010: 65-77.

Ibitokun, B. M. Homo Sapiens and the Mirage of Self-Plenum: A Valedictory Lecture. Ibadan: Kraft Book Ltd., 2014.

Ibitokun, B. M. African Drama and the Yoruba World-view. Ibadan: University of Ibadan, 1995.

Idowu, Baolaji. Olodumare: God in Yoruba Belief. London: Longman Ltd., 1962.

Karenga, Maulana. "Eniyan”. In Molefi Kete Asante and Ama Mazama (eds.) Encyclopedia of African Religion. California: Sage Publications, Inc., 2009, 239-240.

Karenga, Maulana. Odu Ifa: The Ethical Teaching. Los Angeles: University of Sankore Press, 1999.

Makinde, A. M. "African Culture and Moral System: A Philosophical Study". Second Order: an African Journal of Philosophy, 1, 2(1988), 1-27.

Macquarrie, John. Principles of Christian Theology. Revised edition. London: SCM Press, 1977.

4 I am indebted to Prof. Wale Olajide of the Department of Philosophy, Ekiti State University, for a fruitful discussion of this work, and to Dr Oluwole Coker of the Department of English Literature, Obafemi Awolowo University, Ile-Ife, Nigeria, for helping to read the first draft of the manuscript, and for his sharp and constructive criticisms in form of suggestions of addition and subtraction, which greatly enrich the contents of this article. 
Mbiti, John S. African Religions and Philosophy. Oxford: Heinemann Educational Publishers, 1969.

Oke, Moses. "An Existential Reading of Ola Rotimi's The Gods Are Not To Blame”. Odu: Journal of West African Studies, 42(2001), 121-142.

Olajide Wale. "Tautologies as Allegories of Life." Journal of Applied and Environmental Science, 2, 2 (2006): 241.

Olajide Wale. "Socio-Cultural Contentions and the Prospect of Self-Actualisation" Journal of Philosophy and Related Disciplines, 3, 1\&2 (2008): 117.

Olajide, Wale. "Existential Reversals and Yoruba Philosophy." Lumina, 22(2011), 1-15.

Olajide, Wale. "Human Existence and Natural Evil: A Search for Meaning". Terra Sanctum: A Journal of Religion and Peoples, 1, 2(2011), 62-72.

Ogungbemi, Segun. Philosophy and Development, (Ibadan: Hope Publications, 2007).

Priest, Steven. Jean-Paul Sartre: Basic Writings, (New York: Routledge, 2001).

Sartre, Jean-Paul, "Intention and Action." In The Study of Human Nature, ed. Leslie Stevenson, New York: OUP, 1981.

Sartre, Jean-Paul. "Existentialism is Humanism." In Existentialism from Dostoyevsky to Sartre, ed. Walter Kaufman, New York: Meridian Publishing Company, 1956.

Reisinger, Y. and Steiner, C. J. (2006) "Reconceptualizing Object Authenticity". Annals of Tourism Research, 33, 1 (2006), 65-86.

Wiredu, Kwasi. Philosophy and an African Culture. Cambridge: Cambridge University Press, 1980. 